\title{
NATO šiandien: pasiklydę transformacijoje?
}

\begin{abstract}
Šiame straipsnyje aptariama NATO evoliucija ir ateities raidos perspektyvos, nagrinejjami vidiniai prieštaravimai ir dilemos, su kuriomis susiduria Aljanso nariai. Straipsnyje teigiama, kad naujos strateginès koncepcijos rengimo procesas savotiškai atspindi tam tikrą idëjinę NATO krizę ir naujos tapatybės paieškas. Autorius teigia, kad NATO „transformacija“ yra daugiau savitikslis procesas nei aiškus ir visoms narèms priimtinas raison d'etre. Remiantis Roberto Cooperio iškelta teorija, straipsnyje aptariama Aljansui kylanti strateginio disonanso problema. Postmodernios Aljanso narių visuomenès vis mažiau linkusios remti karinius nuotykius toli už NATO teritorijos ribu. NATO operacijos dažnai vyksta ikimodernioje, anarchiškoje aplinkoje, ,ž̌lugusiose“ valstybėse. Tokioms misijoms vykdyti reikia pažangiu technologijų ir visapusiško, integruoto civilinio-karinio veikimo. Pagaliau dauguma už Europos ir Šiaurès Amerikos ribų esančių valstybiụ yra vis dar XX amžiaus tipo modernios, nacionalinės, dažnai nedemokratinės valstybės, kaip Kinija ar Rusija. Pastaroji tebėra svarbus veiksnys, apibrěžiantis Aljanso tapatybę tiek jo viduje, tiek tarptautinëje erdvejje. NATO, kuris siekia tapti pažangiu XXI amžiaus Aljansu, sunkiai randa bendrą kalbą su Rusija, įstrigusia XX amžiaus geopolitinèje pasaulèvokoje, dèl pagrindinių saugumo problemų sprendimo postsuverenioje ir postnacionalinëje Europos erdvëje. Nauja strateginė koncepcija turès apimti visus šiuos, atrodytu, nesuderinamus, ,"disonuojančius“ elementus. NATO nebėra vien regioninis karinis blokas, bet netampa ir visuotiniu politiniu forumu, kuriame būtų sprendžiamos visos svarbiausios tarptautinio saugumo problemos. NATO rengiasi vykdyti tiek „labiausiai tikètinas“ operacijas, tokias kaip Afganistane, tiek sudètingiausias, 5 straipsnio pobūdžio operacijas. Kyla pavojus, kad prioritetą teikdami lengvoms, ekspedicinėms pajėgoms kariauti prieš silpnus, asimetrinius priešus, sajungininkai nebesugebės kariauti konvencinių karų su lygiaverčiais priešininkais, o kad tokie karai Europoje vis dar įmanomi, labai aiškiai priminė Rusija Gruzijoje. Lietuvos 5 metų narystės NATO patirtis taip pat prieštaringa: dalis su naryste sietų vilčiu išsipildè, dalis - ne, o pati Lietuva padarè nemažą pažangą siekdama tapti brandžia sajungininke.
\end{abstract}

\section{Ivadas}

NATO turi daug ịvaizdžių: nuo Vakarų demokratinės bendruomenès triumfo ir šlovès simbolio iki agresyvaus, ekspansyvaus karinio bloko, turinčio piktų ketinimų kitų šalių atžvilgiu.

\footnotetext{
* Dr. Kęstutis Paulauskas - Vilniaus universiteto Tarptautinių santykių ir politikos mokslų instituto lektorius, buvęs (2006-2009 m.) gynybos patarejo pavaduotojas Lietuvos delegacijoje prie NATO. Adresas: Vokiečių g. 10, 01130 Vilnius; tel. 85 2514130, el. paštas - kpaulauskas@gmail.com.

**Autorius dèkoja Davidui Yostui, Vaidotui Urbeliui ir Tomui Janeliūnui už vertingas pastabas ankstesnei šio straipsnio versijai.
} 
Oficialiąja Vakarų versija, NATO yra sėkmingiausias karinis aljansas istorijoje. NATO įveikẻ Varšuvos paktą šaltojo karo priešpriešoje, įvedè taiką Balkanuose, o šiandien skleidžia demokratiją ir garantuoja stabilumą karu nuvargintame Afganistane, kovoja su piratais prie Somalio krantų.

Tuzinui Pietų ir Centrinès Europos valstybių, iškilusių iš komunistinės distopijos griuvèsiu, NATO įkūnija išsipildžiusią saugios ir klestinčios ateities svajonę, o kartu ir suteikia garantiją, kad Europoje sienos nebus iš naujo peržiūrimos. Daugeliui Balkanų ir Rytų Europos šalių tai vis dar yra tolima (o kai kuriais atvejais vis labiau tolstanti) siekiamybè.

Vakaru Europos sajungininkams NATO greičiausiai jau prarado turètą egzistencinę svarbą. Galima daryti prielaidą, kad kai kurioms šalims Aljansas netgi tapo našta ar savarankiškos Europos Sajungos gynybos politikos plètojimo kliūtimi. NATO - ES santykiai vis dar yra įstrigę „,šaltajame konflikte"1 gédingas faktas turint omenyje, kad 21 valstybė yra abiejų organizacijų narè.

Anglosaksų valstybėms - JAV ir Jungtinei Karalystei (toliau - JK) - NATO yra ju globaliu interesu projekcija (JK atveju - labiau praeities ambiciju). Susirūpinimas, kad NATO Vašingtonui tèra ,irrankių dèžè" karinèms avantiūroms igyvendinti, turbūt nepagrįstas, tačiau kai kurių Europos šalių silpstantis įsipareigojimas Aljansui galimai atsispindi Vašingtono sprendimuose, kurie gali neigiamai paveikti Europos saugumą.

Žinoma, yra ir tokių tarptautinės sistemos veikëju, kurie nekenčia NATO. Pirmiausia tai naujasis priešas - Afganistane veikiančios pasipriešinimo pajègos. Talibanui ir Al Qaidai NATO yra tiesiog kitatikių Vakarų nešamo blogio išpera.

Senojo priešo - Rusijos - atveju, NATO tebėra ypač svarbus veiksnys Maskvos strateginiame mąstyme. Rusijos nacionalinio saugumo koncepcija ir karinė doktrina NATO veiklą vertina kaip keliančią grėsmę Rusijos saugumui. Paradoksalu, tačiau NATO išlikimas Maskvai yra netgi svarbesnis negu kai kuriems sajungininkams - NATO yra puikus pretekstas mobilizuoti nepatenkintą visuomenę agresyvaus karinio aljanso akivaizdoje, tik ir laukiančio galimybès užpulti Tèvynę.

Pagaliau Vakarų Europos visuomenės, jau pamiršusios pasaulinių karu siaubą, nebenori savo jaunų vyru ir moteru gyvybiu statyti i pavojų. Organizuotos šių visuomenių grupès - įvairūs antikariniai, antiglobalistų ir kitokie prieš ką nors judẹjimai mato NATO kaip karo ir kraujo ištroškusių generolu klubą, kurị būtina tuoj pat išvaikyti.

Dauguma šių įvaizdžių ir stereotipu yra per daug išpūsti, pernelyg supaprastinti ar tiesiog klaidinantys. Bet kuriuo atveju didelis šiu įvaizdžiu skaičius rodo, kad NATO tebèra svarbi pasauliniu mastu atpažistama, vertinama ar nemėgstama organizacija. Tokiame kontekste šis straipsnis bando atskleisti, kas yra NATO, kas nèra NATO ir kas ji galètų būti pirmame naujo tūkstantmečio amžiuje, žvelgiant iš akademinès, sąlyginai naujos ir santykinai mažos Aljanso narès perspektyvos.

\footnotetext{
${ }^{1}$ Taip NATO - ES santykius savo 2007 m. sausio 29 d. kalboje "NATO and the EU: Time for a New Chapter" apibūdino tuometis NATO generalinis sekretorius Jaap de Hoop Schefferis.
} 
Šiame straipsnyje aptariamos trys pagrindinès tezès:

- NATO (tiesiogine prasme) yra senyvas Aljansas, kuris nuolat stengiasi keistis ir prisitaikyti prie evoliucionuojančios pasaulinès aplinkos. Vis dèlto aiškus NATO egzistencijos tikslas tapo kiek miglotas nuolatinès transformacijos procese.

- Nors NATO imasi vis naujų misiju, naujų veiklos sričių ir naujų partnerysčiu, jos politinis vaidmuo per pastaruosius du dešimtmečius patyrè savotišką infliaciją, nes karinè galia (nors vis dar svarbi) nebėra tokia nepakeičiama, kaip šaltojo karo metais. ${ }^{2}$ Iš čia ir NATO siekis iš naujo save apibrèžti.

- NATO išgyvena savotišką tapatybės krizę: sudėtingos dilemos turės būti įvertintos, o kai kuriais atvejais - priimti ir nelengvi sprendimai.

Straipsnis baigiasi skyriumi, skirtu Lietuvos narystė NATO penkeriu metu patirčiai aptarti. Turbūt pagrindinè šio laikotarpio pamoka yra ta, kad bandomasis laikotarpis baigèsi. Dabar iš esmès nuo pačios Lietuvos priklauso, kaip sẻkmingai jai pavyks įsilieti į Aljanso darbotvarkę nepamirštant nacionalinių interesų.

\section{1. Šešiasdešimtmečio jubiliejaus spindesys ir skurdas}

NATO yra gyvybingas karinis aljansas. Jis pergyveno Varšuvos paktą 36 metus (1955-1991) trukusioje priešpriešoje, retkarčiais balansavusioje ant karo slenksčio. Ne kartą girdetas raginimas organizaciją panaikinti, pasibaigus šaltajam karui. Aljansas atsinaujino jau du kartus, priimdamas i ateiti orientuotą Strateginę koncepciją 1991 m. ir ją peržiūrèdamas 1999 m. tam, kad būtų įvertinta Balkanų karų patirtis ir pasiruošta naujam šimtmečiui. $2009 \mathrm{~m}$. balandị NATO, 28 nariu politinis-karinis aljansas, atšventė savo 60-aji jubilieju Strasbūro-Kèlio miestuose - simbolinëje franko-germaniškos priešpriešos ir susitaikymo vietoje. Dabartiniam NATO, atrodo, ima trūkti ịkvepiančių idejju, ir jis kenčia nuo chroniško strateginio disonanso.

\subsection{Idèjų krizè?}

Viršūnių susitikimo šventinè nuotaika jau seniai išblèso. NATO susiduria su daugeliu, atrodytu, neišsprendžiamų iššūkių. Kai kurie iš jų egzistavo visą NATO istoriją (pvz., Sovietų Sajunga per pirmuosius 40 metu, kurios strateginį iššūkį pakeitè keblūs santykiai su Rusija pastaruosius 20 metų), kitus padiktavo ivvykiai: Balkanų karai 1990-1999 metais (NATO tebėra Kosove); 2001 m. rugsëjo

\footnotetext{
${ }^{2}$ Sovietų Sajunga žlugo, viena vertus, nepaisant jos karinès galios, bet kartu ir dèl jos: neveiksnus sovietų socialinis-ekonominis modelis nebegalëjo išlaikyti globalinès konkurencijos ir dalyvauti ginklavimosi varžybose su Vakarais.
} 
11-osios išpuoliai JAV, atvedę ì besitęsiantị karą Afganistane, ir piratavimo proveržis prie Somalio krantu, tapęs naujausiu NATO darbotvarkės punktu.

Vis nauji iššūkiai paskatino Aljansą imtis savo strategijos revizijos. Sajungininkams, atrodo, sunkiai sekasi apibrèžti XXI amžiaus NATO ir sutarti dèl jo raison d'être. Naujos strateginės koncepcijos kūrimo procesas buvo patikètas 12 išminčių grupei, vadovaujamai Madeleine Albright, o ne svarbiausiems NATO padaliniams - Vyriausiajam politikos komitetui, Vykdomajai darbo grupei ar Kariniam komitetui, rengiantiems visus svarbiausius Aljanso dokumentus.

Koncepciją rengti pradèta beprecedentiškai skaidriu keliu. Pirmojoje konferencijoje, įvykusioje 2009 m. liepos 7 d. Briuselyje, dalyvavo eklektiškas sambūris iš Aljanso narių ir partnerių vyriausybių, NATO struktūrų, tarptautinių organizaciju, pilietinès visuomenès, įskaitant parlamentus, verslo korporacijas, nevyriausybines organizacijas, ",smegenu centrus", akademinius sluoksnius ir žiniasklaidą"3. Šią konferenciją papildė grupė kvaziakademinių seminaru, kuriuose buvo svarstomi įvairūs koncepcijos aspektai.

Pastangos įtraukti kiek įmanoma daugiau įvairių požiūrių į NATO strateginę kryptį aiškiai parodė, kas NATO nebėra - uždaras, slaptas karinis šaltojo karo eros aljansas. Tuo pat metu tai gali reikšti, kad sajungininkai nebėra tikri dèl NATO tikslo ir vaidmens tarptautinejje politikoje ir nebesugeba patys apibrèžti NATO ateities. Albright inauguracinè kalba pirmojoje konferencijoje buvo vienodai gera visoms auditorijoms. ${ }^{4}$ Vis dèlto būti visiems geram nebūtinai yra gera strategija.

Pagirtinas skaidrumo siekis gali maskuoti Aljanso vadovybės negebėjimą pasiūlyti naujų, įkvepiančių idejju, kurios atkreiptų "Google“ kartos dèmesį. Pagal pirmajam NATO generaliniam sekretoriui lordui Hastingsui Ismay'ui priskiriamą formulę NATO tikslas (tačiau ne oficiali politika) buvo keeping the Russians out, the Americans in, and the Germans down. Ši frazè pažadino visos kartos strateginę vaizduotę. 2009 metų NATO, žinoma, skyrèsi nuo 1949 metu NATO. Šiandien yra neįmanoma, kad NATO generalinis sekretorius galètu pasiūlyti toki įsimenanti, bet politiškai jautrų ar net nekorektišką šūkį. Politiškai korektiško diskurso taisyklių nesilaikymas leistų dabartinę situaciją apibūdinti daugmaž taip: getting the Russians in, the Germans up and the Americans out. Iš tikruju, pasibaigus šaltajam karui Vokietija susivienijo, amerikiečiai uždarè daugumą savo karinių bazių ir atitraukè didžiąją savo pajẻgų dalį iš Europos, o Rusija tapo visaverte euroatlantinès saugumo erdvès veikëja.

1992-1993 m. tuometis NATO generalinis sekretorius Manfredas Wörneris gana izžvalgiai teigè, kad NATO reikès „eiti už Aljanso teritorijos ribu arba liautis egzistavus" (ang. go out of area or out of business). Po keleriu metu ir jau turẻdamas Balkanų liūno patirtị, lordas George'as Robertsonas (NATO generalinis sekretorius 1999-2004 m.) tą pranašystę pavertė pernelyg dažnai

\footnotetext{
3 "NATO launches public debate on the Strategic Concept", 7 July 2009, http://www.nato.int/cps/en/natolive/ news_56326.htm?, žiūrèta: 2009-11-28

${ }^{4}$ Albright M., "NATO 2009: Past Lessons, Future Prospects", http://www.nato.int/cps/en/natolive/opinions_56158.htm, 2009-11-29.
} 
naudojama mantra, apibrèžusia NATO ateities paskirtį: taigi NATO turëjo „eiti už Aljanso teritorijos ribų arba trauktis" Šiandien kai kurie analitikai jau su tam tikra ironija teigia, kad nuejjus į Afganistaną NATO gali tekti jau ir trauktis. ${ }^{5}$

Akivaizdu, kad NATO susiduria su komunikacijos problema. NATO nèra itin dažnai minimas ar reikšmingas akronimas Vakarų žiniasklaidoje. Turbūt labiausiai matomas NATO veiklos aspektas yra operacija Afganistane. NATO paprastai įvertinama kaip papildoma, nors ir ne visada konstruktyvi, amerikiečių pastangu stabilizuoti ir rekonstruoti šią šalį dalis. Dėmesys dažnai būna ir negatyvus, pabrěžiamas europiečių nenoras naudoti karinę jègą ir dislokuoti modernius (ir nepigius) pajègumus, tokius kaip sraigtasparniai. Kai sajungininkai panaudoja oro galią, žiniasklaida išpučia civilinių auku problemą.

Buvimas „už teritorijos ribų“ taip pat reiškia buvimą už visuomenès matymo ribų, ypač mažesnių Aljanso narių, neturinčių visuotinių TV tinklų. CNN ar BBC netransliuoja kasdienio Čekijos ar Lietuvos karių gyvenimo Afganistane. Net jei ir transliuotu, dauguma lietuvių vis tiek nežiūrètų. Bet kuriuo atveju: blogos antraštės ar jokių antraščiu - lemia sunkią ir turbūt nelaimimą kovą dèl „širdžių ir protų" Aljanso šalyse. Visuomenès parama yra gyvybiškai būtina siekiant išlaikyti tarptautinių operacijų legitimumą ir tinkamus išteklius joms ilguoju laikotarpiu. Vienintelis kitas NATO veiklos aspektas, suteikiantis jai reguliaraus viešumo, yra nuolatinė Rusijos kritika Aljanso atžvilgiu dèl įsivaizduojamos konspiracijos apsupti Rusijos „teisètų interesų zoną".

Viešasis NATO veidas, be abejonės, keičiasi. Prie NATO prisijungus dvylikai Vidurio, Rytu ir Pietų Europos valstybių, NATO tapo įvairesnè ir tam tikra prasme jaunesnè organizacija (dauguma naujesnėms NATO narėms atstovaujančių ambasadorių Siaurès Atlanto taryboje yra jaunesni už jų kolegas iš Vakarų).

Be to, naujoji lyderių karta tiesiog neprisimena tamsiausių šaltojo karo dienų. Barrackas Obama dar buvo studentas ir ",bendruomenès organizatorius", o Nicolas Sarkozy ir Angela Merkel buvo tik bepradedantys savo politines karjeras 9-ajame praejjusio amžiaus dešimtmetyje, kai šaltasis karas ejjo į pabaigą. Jie subrendo kaip valstybiu lyderiai tais metais, kai istorija buvo pristabdyta „taikos dividendams" suskaičiuoti. Jų praeitis lèmė ju politines pažiūras, kurioms ypač būdingos pragmatizmo, atvirumo, dialogo ir bendradarbiavimo vertybès, o ne šaltojo karo eros ideologija, izoliacija, konfrontacija ar paranoja. Šiu pokyčių rezultatai jau matomi - po 43 metų pertraukos į NATO karines struktūras grįžo Prancūzija.

Tuo pat metu Šiaurès Atlanto taryba ir toliau lieka gana uždaras senyvu, pasiturinčių baltujų vyrų klubas. Moterys ar kitokios rasės žmonès yra itin didelè retenybė prie apskrito jos stalo (jau nekalbant apie generalinio sekretoriaus postą). Būtų galima teigti, kad antropologiniu požiūriu šis subjektyvus faktas riboja Šiaurès Atlanto tarybos pasaulèžiūrą, nors tarptautinès politikos prigimtis nuolat keičiasi. Platesniu, teoriniu požiūriu, NATO vis dar galima

${ }_{5}^{5}$ Žr. pvz.: Patrick S.M., “Out of Area, Out of Business?”, National Interest Online, 25 March 2009. 
apibūdinti kaip savotišką etatocentrišką organizaciją, kuri funkcionuoja klasikiniu teritorijos, suvereniteto, karinės galios kategoriju pagrindu. Šia prasme Aljansas yra XX amžiaus geopolitikos kūdikis. Patirtis Afganistane, nors ir lètai, bet keičia šią realybę. Technologiju pažanga ir nekontroliuojami globalizacijos procesai sudaro prielaidas mobilesnès ir politiškai sąmoningesnès tarptautinès bendruomenès plètrai. Anksčiau ar vèliau, Aljanso narès turès prisitaikyti prie šios naujos realybės.

Paprastas NATO 60-ojo jubiliejaus logotipo palyginimas su Rusijos Federacijos misijos prie NATO logotipu išsamiau iliustruoja aptartos idejjų krizės regimybę (žr. 1 paveikslą). NATO atrodo pasiklydusi transformacijoje, o jos partnerio Rusijos simbolika spinduliuoja visišką pasitikëjimą savimi ir aišku savo tikslų ir politikos suvokimą.
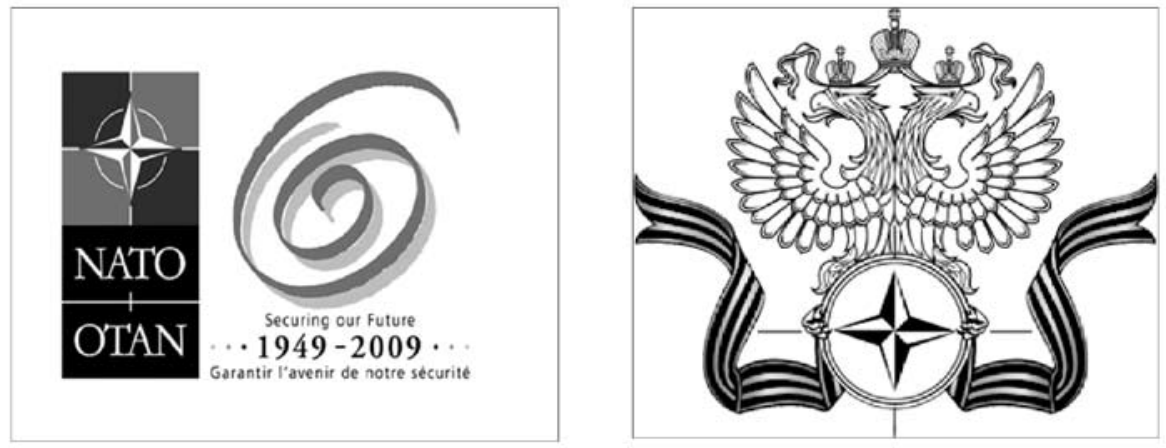

1 pav. NATO idèjų krizè

\subsection{Strateginis disonansas}

NATO patiria strateginio disonanso problemą, kuri kyla iš susidūrimo tarp to, ką Robertas Cooperis vadina ikimoderniomis, moderniomis ir postmoderniomis valstybèmis. ${ }^{6}$

Dauguma Aljanso nariu gali būti laikomos „postmoderniomis“ visuomenėmis, kurios yra turtingos, pasaulietiškos ir emancipuotos. Sienos, nacionalinis suverenitetas, karinè galia nebedominuoja vidiniame politiniame diskurse ne tik Vakaru Europoje, bet vis labiau ir likusioje jos dalyje. Žmonèms yra svarbiau jų namų ūkio klestëjimas ir saugumas ju miestų ir miesteliu gatvėse, o ne tankų ar branduolinių raketų skaičiai priešiškoje supervalstybejje, kaip buvo šaltojo karo laikais. Tai postnacionalinės, postsuverenios ir postteritorinės bendruomenès, kurioms ",nacionalinių sienų“ ir "nacionalinio intereso“ sąvokos tampa miglotais praeities prisiminimais.

Taip nẻra daugelio modernių nacionalinių valstybių atveju, pradedant

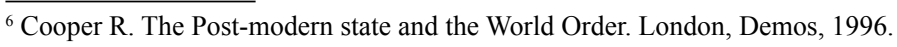


vadinamosios BRIC (Brazilija, Rusija, Indija, Kinija) grupės šalimis ir baigiant didžiaja dalimi likusių valstybiu už Šiaurès Amerikos ir Europos ribų. ${ }^{7}$ Tai pasaulis, kuriame XX ir net XIX amžiaus taisyklès tebegalioja: centralizuota nacionalinè valstybė, besiremianti viena dominuojančia etnine grupe, yra pagrindinis piliečių gyvenimo elementas. Vidaus politikoje piliečiai yra subordinuoti ir tarnauja valstybės tikslams. Valstybès interesas yra aukščiau individo intereso. Tarptautiniuose santykiuose saugumo dilema diktuoja nulinès sumos žaidimo logiką ir nuolatinę galios balanso paiešką.

Pagaliau pasaulio žemèlapyje yra ir tokių dèmių, kuriose nacionalinės valstybės projektas žlugo beveik iš karto po kolonijinės eros pabaigos. Tokiose vietose centrinė vyriausybė yra arba silpna, arba iš viso neegzistuoja. Vidaus politika - tai kelių grupuočių ar genčių tarpusavio kova. Žmogaus orumas ar gyvybė čia neturi jokios vertès, nekalbant apie pagrindines žmogaus teises. Siandien tokios ,žlugusios valstybès“ pavyzdys - Somalis, tačiau Afganistanas su savo gentine-klanine politika ir beveik genetišku imunitetu vakarietiškai demokratijai taip pat gali būti laikomas ikimoderniu dariniu.

Postmodernių visuomenių susidūrimas su moderniomis nacionalinèmis valstybėmis lemia nuolatinį nesusikalbẹjimą ir nesusipratimus, panašius i tuos, kurie kartojasi tarp, pavyzdžiui, NATO ir Rusijos, ES ir Rusijos ar ES ir Kinijos. Tokios valstybès kaip Rusija ar Kinija energingai siekia nacionalinių interesu - taip, kaip juos apibréžia politinis šių šalių elitas, kurių atsakomybẻ visuomenei apsiriboja įsipareigojimu palaikyti minimalius (iš)gyvenimo standartus. Bet koks visuomenès ar jos grupių bandymas siekti alternatyviu politinio gyvenimo organizavimo būdų yra iš esmès už įstatymo ribų. Svarbiausias nacionalinis interesas šiam elitui yra valdančiojo režimo išlaikymas bet kokiomis priemonėmis. Šiaurès Amerikos ir Europos valstybiu politikams pagrindinès sprendimu prièmimo prielaidos yra demokratinis teisètumas ir viešasis gèris, nes tik jos gali padèti išlaikyti valdžią po eilinių rinkimų. Šis skirtumas yra pernelyg fundamentalus, kad galètų būti užglaistytas „,bendrų interesų" retorika. Nors abi pusès gali demonstruoti interesą to paties objekto ar klausimo atžvilgiu, to intereso prigimtis bus visiškai skirtinga.

Vakaru šalių susidūrimai su ikimodernia erdve yra dar kitokio pobūdžio iššūkis. Nacionalinė gynyba po šaltojo karo pabaigos gerokai smuktelèjo Vakarų valstybių prioritetų sąrašuose. Politinis, karinis ir pramoninis elitas suformulavo "karybos revoliucijos“ (ang. Revolution in Military Affairs) idejją. Jos esmé - pažangių technologijų diegimas karyboje ir naudojimas moderniame mūšio lauke. Tai turètu padėti išsaugoti žmonių gyvybes.

NATO savo ruožtu pradejjo plètoti gynybos transformacijos koncepciją, kuri ženklino perëjimą nuo sunkiu, šarvuotu, teritoriniu pagrindu organizuotu

\footnotetext{
${ }^{7}$ JAV turbūt galima laikyti įdomiu tarpiniu atveju, kuriame reiškiasi įtampa tarp postmodernios visuomenès, esančios globalizacijos ir laisvosios prekybos priešakyje, ir modernios nacionalinès valstybès su izoliacionistiniais ir protekcionistiniais instinktais. Bet kuriuo atveju galima teigti, kad JAV yra daug labiau „postmodernios“" nei bet kuri iš BRIC šalių. Platesnè diskusija šiuo klausimu pateikiama šiame straipsnyje: Posen B.R., Ross A.L. "Competing Visions for U.S. Grand Strategy", International Security, 1996/97 winter, vol 21, no 3 .
} 
ir daugeliu atvejų iš šauktinių sudarytų kariuomenių prie lengvesnių, mobilesnių, bet geriau ginkluotų ir greitai išskleidžiamų profesionalių vienetų, pasirengusių ekspedicinėms operacijoms toli už Aljanso sienų. Vienintelè šių perspektyvių idèju problema buvo visuomenès paramos joms stoka. Rugsejjo 11-osios išpuoliai suteike tarptautinei operacijai Afganistane reikalingą legitimumą. Praëjus aštuoneriems metams, Vakaru visuomenės ima vis mažiau toleruoti augantį aukų skaičių, vis mažiau supranta sajungininkų buvimo Afganistane ar panašiose vietose priežastis, o dažnai yra tiesiog abejingos tų žmoniu, kuriems jų kariai bando padèti, gerovei.

\section{Kuri raison d'être?}

Gera strategija turètų apimti nuoseklų ir kryptingą turimų priemoniu panaudojimą efektyviais būdais, siekiant užsibrèžtų tikslų. Kad NATO naujoji strateginė koncepcija veiktų, ji turètų aiškiai apibrèžti pagrindinį tikslą, kaip tai padarẻ ankstesnès jos versijos. Bent iki rugsejjo 11-osios tas tikslas nebuvo prieštaringas - kolektyvinė NATO teritorijos ir gyventoju gynyba nuo išorinio priešo, kurị praeityje įkūnijo Sovietų Sajunga. Rugsejjo 11-oji sugriovė NATO planuotoju strateginę vaizduotę ir pakeitè supratimą apie ataku, kurių sajungininkai turètų tikètis ateityje, pobūdį. Padaryta prielaida, kad siekiant užkirsti kelią tokioms atakoms, NATO kolektyvinè gynyba turi prasidèti ties Hindukušu, o ne prie NATO - Rusijos sienu. Problemos esmė yra tokia: ar įmanoma suderinti NATO istorinę raison d'źtre - NATO teritorijos gynybą - su naujai atrastu pareigos jausmu kurti taika, saugumą ir gerovę tokiose nuo NATO teritorijos nutolusiose vietose kaip Afganistanas ar Somalis?

\subsection{Afganistanas}

NATO veikla Afganistane šiandien apibūdina Aljansą labiau nei bet kas. 2009 m. žiemą NATO sąjungininkai buvo įstrigę šioje šalyje su labai miglotomis perspektyvomis iš jos sėkmingai pasitraukti. Afganistano karas kartais pavadinamas „užmirštu“ ar „nelaimimu“ karu. 2009 m. spalio 7 d. suejo jau aštuoneri metai, skaičiuojant nuo operacijos „Tvari laisve“" pradžios, kurią greitai užtemdè „Irako laisvès" operacija (iš čia ir „užmiršto“ karo metafora). NATO ėmèsi perimti atsakomybę už visą šalį jau 2003 m., o karo pabaigos kol kas nematyti (todèl šis karas „nelaimimo“). Vis dèlto ISAF (ang. trump. International Security Assistance Force) misija Afganistane apibrėžia XXI amžiaus NATO. Visos 28 sajungininkès yra visiškai įsipareigojusios šiam bendram tikslui, dislokuodamos savo pajègas ir/ar civilinius ekspertus. Prie misijos prisideda 15 partnerių, o bendras karių skaičius yra apie 71000, remiančių (arba remiamų) 
94000 Afganistano nacionalinės armijos karių. ${ }^{8}$ NATO dirba, bendradarbiauja ir kartais net koordinuoja savo veiklą su kitomis tarptautinėmis organizacijomis, pirmiausia Jungtinių Tautų misija Afganistane - UNAMA (ang. trump. United Nations Assistance Mission in Afghanistan) ir ES, ir daugybe įvairių nevyriausybinių veikëjų. Pats operacijos pobūdis yra reikšmingas keletu aspektų: ji buvo sumanyta kaip NATO atsakas į rugsëjo 11-osios išpuolius JAV, taigi tam tikra prasme tai 5-ojo straipsnio operacija, t.y. Aljanso teritorijos ir gyventoju gynyba. Sis pradinis sumanymas greitai peraugo į milžinišką saugumo, stabilizavimo, rekonstravimo, mokymo ir plètros ir net valstybès kūrimo operaciją, vykstančią priešiškoje aplinkoje ir labai toli nuo Aljanso narių sienų (kitaip nei ankstesnès didelès NATO operacijos Balkanuose).

NATO vadovybè Afganistaną laiko esminiu organizacijos politinio gyvybingumo ir karinio patikimumo patikrinimu. Jau minėtas NATO generalinis sekretorius Robertsonas yra pasakęs, kad NATO turi eiti į Afganistaną, arba Afganistanas ateis į NATO. Aljanso saugumo deklaracija aiškiai teigia, kad Afganistanas yra "pagrindinis NATO prioritetas“. Kitas buvęs NATO generalinis sekretorius Jaapas de Hoopas Schefferis nuolat kartojo, kad nuo sėkmès Afganistane priklauso NATO patikimumas. Turint omenyje ribotus ligšiolinius laimëjimus, nesėkmès kaina tikrai gali būti aukšta.

Operacija Afganistane įkvėpė NATO naujos gyvybės po iš esmès sèkmingai išspręstų Balkanų problemų. Ne mažiau svarbu ir tai, kad ji palaiko Aljanso vardą naujienų antraštėse. Net jei žiniasklaida labiau mėgsta eskaluoti negatyvius aspektus (civilių aukos, nesėkmės kovojant su narkotikų gamyba, šiurkštūs pažeidimai per 2009 m. vykusius prezidento rinkimus, augantis savižudžiu ataku skaičius ir t.t.), net ir toks jos dėmesys gelbsti NATO nuo visiškos nežinios interneto kartos akyse. Būtent ši karta greitai taps pagrindiniais mokesčių mokètojais, nuo kurių galiausiai priklausys visų sajungininkių gynybos biudžetai. Kita vertus, ISAF apibūdinimas fatalistiniais terminais - „pavyks, arba žlugsime“" (ang. make or break), iš tikruju gali kelti pavojų ilgalaikiam NATO patikimumui, nes nei Afganistanas, nei kita panaši operacija ateityje nesibaigs paprastu "laimëjimu“ ar "pralaimëjimu“, bet greičiau bus neterminuotas, ilgalaikis įsipareigojimas.

Vis dèlto galima teigti, kad NATO yra vienintelè žaideja šioje aukščiausioje tarptautinių operacijų lygoje: kad ir koks būtų jos buvimo Afganistane rezultatas, jokia kita tarptautine organizacija negali dislokuoti ir išlaikyti tiek daug pajėgu, vykdančių tokią sudètingą civilinę-karinę misiją tokị ilgą laikotarpi tokiu dideliu atstumu nuo namų.

NATO įsipareigojimas Afganistane sudaro nemažą kontrastą tam, ko NATO negalëjo ar nenorëjo daryti kitose pasaulio dalyse, įskaitant savo pačios periferiją. Irako karas buvo vienas labiausiai Aljanso vienybę supurčiusiu įvykių NATO istorijoje. Žemiausias taškas buvo pasiektas amerikiečių invazijos išvakarèse, kuomet NATO ilgai nesugebėjo susitarti, kaip atsakyti i Turkijos prašymą sustiprinti jos gynybą. Nors transatlantinis ryšys daugiau ar mažiau

${ }^{8}$ NATO tinklalapio informacija, http://www.nato.int/isaf/docu/epub/pdf/isaf_placemat.pdf, 2009-10-22 
"sugijo“, o NATO igyvendina savo nedidelę mokymo misiją Irake nuo 2004 m., minètas epizodas paliko tam tikrą dèmę ant abipusės gynybos įsipareigojimo tarp visu sajungininkių.

NATO iš esmès nepaisant regiono artumo ir strateginės svarbos nedalyvauja sprendžiant konfliktus ir Artimuosiuose Rytuose. Nors NATO, be kita ko, yra branduolinis aljansas, nėra niekaip įsitraukusi į Irano branduolinio galvosūkio sprendimą. Nepaisant pastangų plètoti platų partnerysčių tinklą, įskaitant Stambulo bendradarbiavimo iniciatyvą ir Viduržemio jūros dialogą, NATO nevaidina jokio vaidmens ir Izraelio konflikte su arabu šalimis ir nevalstybiniais militarizuotais veikejais - „Hamas“ Palestinoje ar "Hezbollah" Libane. Toks NATO absenteizmas regione, kuris yra esminis visuotinio saugumo dèlionès elementas, yra sunkiai suprantamas.

Izraelis nèra Euroatlantinės partnerystės tarybos narys, o tiek Rusija, tiek Gruzija buvo netgi institucionalizavusios savo partnerystę su NATO, tačiau šis faktas niekaip nepadejo išvengti jų tarpusavio karo. Paradoksalu, tačiau tas pats faktas galëjo būti ir vienas iš konflikto šaltinių.

\subsection{Rusija - kebli, bet nepakeičiama}

Rusija didele dalimi tebėra moderni nacionalinè valstybė, kurios kai kurie regionai, pirmiausia Šiaurès Kaukazas, netgi grimzta į ikimodernią, anarchišką būklę. Lyginant su ES - vis labiau postmodernia ir postnacionaline erdve - NATO kaip politinis karinis aljansas su stipriomis šaknimis XX amžiuje, atrodytu, yra geriau pasirengusi, atsižvelgiant i situaciją, suprasti Rusiją, bendradarbiauti ir konfrontuoti su ja. Vidinè itampa tarp poreikio transformuotis ir tradicinių saugumo grèsmių ši NATO pranašumą iš esmès eliminuoja. Dẻl to Aljansas tiesiog neturi nuoseklios Rusijos politikos ir tegali pletoti keblu santyki, kuriame po kiekvieno žingsnio į priekį - du žingsniai atgal. Ši įtampa ypač išryškejjo Gruzijos karo metu. ${ }^{9}$

NATO sugebèjo paskelbti ,jokiu ịprastinių reikalų" principą (ang. no business as usual) po Rusijos karinès invazijos į Gruziją 2008 m. rugpjūčio 8 d., bet tik tam, kad po keliu ménesiu de facto pripažintų naują realybę ir grị̌žtu prie ,„iprastinių reikalu“ ir net "naujos pradžios ${ }^{\prime \prime}{ }^{10}{ }^{1}$ Konfliktas ịvyko tarp dvieju NATO partnerių: viena šalis dalyvauja bendru lygmeniu (NATO-Rusijos Taryboje), o kitai buvo pažadėta narystė NATO Bukarešto viršūnių susitikimo metu 2008 m. Pastarasis faktas nesulaikė Gruzijos nuo kvailo pasidavimo Rusijos provokacijoms, o NATO-Rusijos Tarybos egzistavimas nesulaikè Rusijos nuo brutalaus atsako ir Gruzijos dalies okupacijos. Galiausiai konfliktą sustabdè ne NATO, bet ES Tarybai pirmininkavusios Prancūzijos prezidentas. Lyg tokio

\footnotetext{
${ }^{9}$ Erlanger S., "West is struggling to unite on Georgia", International Herald Tribune, 2008-08-18 ${ }^{10}$ Žr. "NATO and Russia: A New Beginning", speech by NATO Secretary General Anders Fogh Rasmussen at the Carnegie Endowment, Brussels, 18 september, 2009, http://www.nato.int/cps/en/natolive/ opinions_57640.htm, 20100520 .
} 
pažeminimo būtų maža, $2008 \mathrm{~m}$. rugsèjį buvo atskleistas didžiulis Aljanso informacijos saugumo pažeidimas, kai aukšto rango Estijos pareigūnas buvo sulaikytas už daugybės įslaptintų dokumentų perdavimą Rusijai. Nors ir pavèluotai, NATO savo reputaciją bent iš dalies pataisè išvarydama du Rusijos šnipus formalių NATO - Rusijos Tarybos susitikimų atnaujinimo proga 2009 m. balandi. ${ }^{11}$

Sovietų Sajunga įprasmino NATO raison d'être šaltojo karo metais. Šiandien Rusija tebėra ypač svarbus veiksnys, apibrěžiantis Aljanso tapatybę. Pirmiausia, keletas Aljanso narių, ypač iš rytinès Europos dalies, vis labiau revizionistinès Rusijos politikoje įžvelgia įvairių tikrų ir ísivaizduotų saugumo iššūkių. Tarp ju - energetinès ir kibernetinès grèsmès, kišimasis į vidaus politiką ir ekonomiką, o po karo Gruzijoje - ir susirūpinimas karine grèsme. Šis nesaugumo jausmas buvo labai aiškiai išreikštas atvirame laiške JAV prezidentui Obamai, kuri pasirašè daugelis iškilių Vidurio ir Rytų Europos politikų. ${ }^{12}$

Antai nors dauguma Vakarų Europos valstybių šio susirūpinimo nesupranta, pačios nesugeba su Rusija sukurti stabilios ilgalaikès partnerystès, kurios netemdytų įvairūs besikartojantys nemalonumai kaip energijos išteklių tiekimo Europai sustabdymas, žinomų asmenų žmogžudystès, neprognozuojama teisinè ir ekonominė Vakarų verslo Rusijoje aplinka ir Rusijos politinis, o dabar ir karinis kišimasis į Rytų Europos kaimyninių šalių gyvenimą.

Trečia, NATO - Rusijos ryšys yra išties abipusis - Rusija yra viena iš labai nedaugelio šaliu, kurios atidžiai stebi kiekvieną NATO veiksmą, reakciją ar pareiškimą. Labai dažnai būtent Rusijos pareigūnų negatyvūs pasisakymai apibrėžia NATO įvaizdį visuomenės akyse. Tai savaime nėra blogai, nes neleidžia išnykti NATO temai iš pirmuju puslapių.

Žurnalas The Economist yra išreiškęs nuomonę, kad „rusai jau turbūt pasiekẻ beveik viską, ko sieke்", o būtent - sustabdè tolesnę NATO plètrą ir priešraketinès gynybos dislokavimo Rytų Europoje planus. ${ }^{13}$ Šis teiginys remiasi prielaida, kad Rusija NATO ir JAV atžvilgiu turi aiškią strategiją, kurios galutinis tikslas yra euroatlantinès saugumo architektūros rekonstravimas, suteiksiantis Rusijai visas sprendimu prièmimo teises visais Europos saugumo klausimais. ${ }^{14}$ To paties negalima pasakyti apie sajungininkus. Iš tikruju koordinuoto požiūrio, nekalbant apie strategiją, Rusijos atžvilgiu akivaizdžiai trūksta. NATO komunikatų skirsniai, skirti partnerystei su Rusija, yra ypač keblūs, perpildyti didžiulių vilčių ir tikëjimo neįtikẻtinu bendradarbiavimo potencialu, ir kartu švelniai grūmojantys Rusijai už neigyvendintus įsipareigojimus

\footnotetext{
${ }^{11}$ Barber T., "Russians expelled in NATO spy storm", Financial Times, April 30, 2009

${ }^{12}$ Žr. "An Open Letter to the Obama Administration from Central and Eastern Europe", Gazeta Wyborcza. pl, 200907 15, http://wyborcza.pl/1,75477,6825987,An_Open_Letter_to_the_Obama_Administration_from_Central.html, 20100520.

13 “A new balance in Europe", The Economist, 21 Nov 2009, p. 36.

${ }^{14} 2009$ m. lapkritị Rusijos prezidento paskelbtas siūlomos „Europos saugumo sutarties“ tekstas gana atvirai išdèsto ši strateginį tikslą. Žr. President of Russia, Official Web Portal, http://eng.kremlin.ru/eng/text/ themes/2009/11/291600_223080.shtml, 20100510.
} 
Gruzijoje ar Sutarties dèl ịprastinès ginkluotès Europoje „moratoriumą“ (Rusija vienašališkai sustabdè savo dalyvavimą šiame režime 2007 metais). Ši klampi pozicija banaliai aiškinama požiūrių skirtumais tarp sajungininku, kurie buvo vakarinëje geležinės uždangos pusëje, ir tų, kuriuos Vakarų žiniasklaida iki šiol vadina „pokomunistinėmis“ valstybėmis. Galima daryti prielaidą, kad šiuos skirtumus puikiai suvokia ir jais naudojasi sprendimų priėmëjai Maskvoje.

NATO - Rusijos bendradarbiavimo „strateginè svarba” aiškinama dviem populiariais aspektais. Pirma, teigiama, kad politinis dialogas yra vertybė savaime, padedanti stiprinti tarpusavio pasitikëjimą, o kartais - išvengti konfliktų. Nors NATO - Rusijos formalūs ryšiai buvo užmegzti dar 1997 m. ir toliau plètoti pasirašant Romos deklaracija, kuria 2002 m. buvo įsteigta NATO Rusijos taryba, naujoji Rusijos saugumo strategija, priimta 2009 m., ir nauja karinè doktrina, priimta $2010 \mathrm{~m}$. pradžioje, labai aiškiai įvardija NATO keliamą saugumo grèsmę Rusijai. Tai tiek dèl to pasitikëjimo. Konfliktų prevencijos atveju nè vienas ,išaldytas" konfliktas bendroje kaimynystëje nebuvo išspręstas net pasitelkus NATORusijos Tarybos forumą, o vienas "karštas" konfliktas kilo nepaisant šios Tarybos.

Antra populiari priežastis, palaikanti bendradarbiavimo NATO-Rusijos Taryboje iliuziją, yra kova prieš bendrus iššūkius saugumui, pirmiausia terorizmą ir masinio naikinimo ginklu platinimą. Šiuo atveju, kaip rodo Irano patirtis, Rusija yra daugiau rizikos veiksnys nei pagalba. Dėl terorizmo grèsmès pora Rusijos laivų keletą savaičių per pastaruosius penkerius metus iš tikrujų praleido patruliuodami Viduržemio jūroje kartu su NATO laivais, vykdančiais antiteroristinę operaciją. Be to, Rusija suteikè nekarinio tranzito teises NATO pajègu Afganistane aprūpinimui, nors kartu darè viską, kad užkirstų tokiam tranzitui kelią per Kirgiziją. Tuo pat metu Maskvai nepavyko iki galo įtikinti Vakaru, kad jos susidorojimas su Čečènija buvo išskirtinai antiteroristinio pobūdžio operacija, nors kai kurios čečènų separatistų operacijos (ypač mokyklos Beslane užgrobimas) padidino simpatijas rusiškajai čečènų tragedijos versijai.

\subsection{Plètros dèlionè}

NATO plètra buvo netiesioginis NATO - Rusijos santykių elementas nuo pat Berlyno sienos griuvimo. 1996 m. gruodi, siekdama nuraminti Rusija, NATO vienašališkai paskelbė, kad dèl plètros Aljanso branduolinè laikysena nesikeis ir NATO „neturi intenciju, planų ir priežasčių dislokuoti branduolinius ginklus naujų narių teritorijoje“.${ }^{15} 1997$ m. steigiamasis NATO - Rusijos aktas, kuriuo buvo sukurta Jungtinè nuolatinė taryba, numatė NATO pasižadejjimą susilaikyti nuo papildomo nuolatinio "didelių kovinių pajėgų dislokavimo“. ${ }^{16}$

\footnotetext{
15 "NATO's Nuclear Forces in the New Security Environment", http://www.nato.int/issues/nuclear/secenvironment.html

${ }^{16}$ Founding Act on Mutual Relations, Cooperation and Security between NATO and the Russian Federation signed in Paris, France, 27 May 1997,

http://www.nato.int/cps/en/natolive/official_texts_25468.htm
} 
Šios nuostatos padejjo Rusijai nuryti pirmūjų buvusio Varšuvos pakto narių Lenkijos, Čekijos ir Vengrijos - prisijungimą prie NATO. NATO-Rusijos Tarybos sukūrimas, kai visos narès dalyvauja lygiomis teisemis ir priima sprendimus konsensusu, buvo viena iš svarbiausių prielaidu $2004 \mathrm{~m}$. pletros raundui, apėmusiam dar 7 Vidurio ir Rytų Europos valstybes.

Tam tikra prasme tai galima laikyti didžiuoju sandèriu, kurio esmè ta, kad NATO galutinai atsikrato savo antirusiško įvaizdžio ir rekonstruoja save pozityvia linkme kaip organizacija, siekiančią taikos ir stabilumo. Iš tikruju, du sẻkmingi plètros raundai smarkiai išplètė saugumo ir taikos erdvęi irytus ir pietus. Pati plètra èmé atrodyti kaip naujoji NATO raison d'être, nors ji gyvavo labai trumpai.

Nepaisant Romos deklaracijos patoso, žadejjusio naują NATO - Rusijos santykių kokybę, tie santykiai palaipsniui tik blogëjo: pirmiausia, Rusija staiga sustabdè savo dalyvavimą Sutartyje dèl ịprastinès ginkluotès Europoje, kuri iki tol laikyta „Europos saugumo pamatu”. Santykiai pasiekè šalčiausią tašką per $2008 \mathrm{~m}$. Gruzijos karą. Gruzijos ir Ukrainos NATO narystės siekiai buvo viena svarbiausiu santykių blogëjimo priežasčių. Rusijos prezidento Dmitrijaus Medvedevo $2008 \mathrm{~m}$. birželį iškelta "naujos Europos saugumo architektūros“ idëja ir nuo to laiko nuolat propaguota gali tapti naujo "paslauga už paslaugą" (ang. quid pro quo) sandèrio pagrindu, panašiu į tuos, kurie įvyko prieš pirmus du plètros raundus.

Visa tai galiausiai siejasi su NATO tapatybès klausimu: kiek toli ir kodèl NATO turètu plèstis? Kurios valstybės gali ir kurios negali tapti NATO narèmis? Kodèl sajungininkų skaičius beveik padvigubëjo po šaltojo karo, kuris buvo Aljanso egzistavimo priežastis? Pirminis šaltinis - Šiaurès Atlanto sutarties 10 straipsnis teigia, kad sajungininkai ,gali visuotiniu sutarimu pakviesti bet kurią kitą Europos valstybę, galinčią prisidèti prie šios sutarties principu igyvendinimo ir saugumo Šiaurès Atlanto erdvëje, prisijungti prie sutarties“. Teoriškai tiek Ukraina, tiek Gruzija turètų būti laikomos tinkamomis narystei (tai pati NATO pripažino Bukarešto viršūniu susitikime), jeigu jos "gali prisidèti prie saugumo Šiaurès Atlanto erdveje". Kaip ir 1999 m. bei 2004 m. plètros atvejais, svarbiausias klausimas yra šis: ar naujų narių prièmimas nepaisant Rusijos prieštaravimų didina ar mažina euroatlantinį saugumą? Du precedentai diktuoja teigiamą atsakymą. Kita vertus, politinio ir visuomeninio konsensuso Ukrainoje nebuvimas ir Gruzijos teritorinio integralumo problemos gerokai apsunkina abiejų šalių perspektyvas. Vis dèlto taip pat yra aišku, kad sprendimas atidaryti duris naujiems nariams yra politinis: jeigu visi sajungininkai sutars, kad šalis yra verta prisijungti prie NATO, taip ir atsitiks, neatsižvelgiant į valstybès "galëjimą prisidèti“.

\section{Sveiko proto NATO}

NATO patiriami sunkumai stabilizuojant ir rekonstruojant Afganistaną ir neapsisprendimas dèl politikos Rusijos atžvilgiu lemia būtinybę grižti ir iš naujo įvertinti NATO ištakas ir atsakyti į esmines koncepcines dilemas. Kad NATO išliktu „,sékmingiausiu aljansu istorijoje“, ji neturètų leisti išoriniams 
veiksniams nulemti jos vaidmens pasaulyje, o laikytis „NATO pirmiausia" principo, kuris leistų atsakyti į paprastą klausimą: ką NATO galètu, gebėtų ir turètų daryti dinamiškoje XXI amžiaus saugumo aplinkoje?

\subsection{Regioninis karinis blokas ar tarptautinis politinis aljansas}

Šaltojo karo NATO tam tikra prasme yra „nuobodi“ organizacija. Ji turèjo vienintelį tikslą: atgrasinti, o atgrasinimui žlugus - apginti Aljanso nares nuo sovietų konvencinės ir branduolinès agresijos. Vašingtono sutartis gana griežtai apribojo NATO operaciju erdvę: sutarties preambulejje sajungininkai įsipareigojo „,siekti stabilumo ir gerovés Šiaurés Atlanto erdveje“, t.y. NATO - Europa ir NATO - Šiaurès Amerika. Karinis kolektyvinės gynybos tikslas nustelbè jos politinį vaidmenį ir politinio konsensuso siekimo platformos svarbą. Nors NATO ịkūnijo transatlantinį ryšį, abi jo pusės plètojo skirtingą ir kartais net nesuderinamą politiką Sovietų Sąungos atžvilgiu. Pavyzdžiui, amerikietiškoji „Sulaikymo“ doktrina ir net détente koncepcija buvo visiškai skirtingos prigimties nei vokiečiu Ostpolitik, kuri iš esmès prièmė naujaji status quo Europoje.

NATO karinės struktūros buvo pasirengusios vienam totaliniam karui. Sajungininkų kariuomenès buvo masinès, sudarytos iš sunkių šarvuotų divizijų ir daugeliu atveju pagrịstos visuotiniu šaukimu (išskyrus JAV, atsisakiusias šauktinių po pralaimëjimo Vietname 1973 m., ir Jungtinę Karalystę, nutraukusią šaukimą 1960 m.). Potencialaus konflikto priešakyje buvo jungtinès mobilios pajėgos Europoje, kurios buvo sudarytos iš įvairių iš anksto suplanuotų daugianacionaliniu junginių, pasirengusių išskleidimui penkiuose regionuose Siaurès ir Pietų Europoje. ${ }^{17}$ Toks šiu pajègu organizavimo principas turëjo užtikrinti, kad prasidèjus Trečiajam pasauliniam karui iš fronto linijos grižtu kiek įmanoma daugiau skirtingų valstybių vèliavų ant žuvusių karių karstų, o tai savo ruožtu užtikrintu, kad jokia sajungininkè negalètų išsižadèti savo kolektyvinès gynybos įsipareigojimo. JAV Europoje nuolat laikè apie 200000 karių, daugiausia iš jų - Vakarų Vokietijoje - pagrindiniame „blogiausio scenarijaus" mūšio lauke. Didelis amerikiečių branduolinis skètis virš Aljanso taip pat užtikrino, kad išlaidos tam „blogiausiam scenarijui“ atrodytų nepakeliamos net pačiai beatodairiškiausiai sovietinei vadovybei.

Visa šita "beprotiška" abipusiškai garantuoto susinaikinimo (angliškų žodžių žaismas mad - beprotis ir MAD - mutually assured destruction) logika griuvo kartu su Berlyno siena. Nuo to laiko NATO transformuojasi, o transformacija dažnai suvokiama ir aiškinama kaip procesas, bet ne galutinis tikslas. Kai kurios esminès dilemos, su kuriomis susiduria NATO, pateikiamos 1 lentelèje.

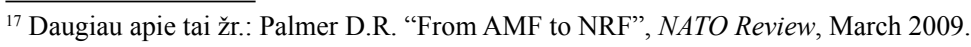




\begin{tabular}{|lll|}
\hline ŠALTOJO KARO NATO & VS. & XXI AMŽIAUS NATO? \\
\hline REGIONINIS BLOKAS & GLOBALUS NATO \\
\hline KARINIS ALJANSAS & $\longrightarrow$ & POLITINIS FORUMAS \\
\hline KARIAVIMAS & VISAPUSIS POŽIŪRIS \\
\hline $\begin{array}{l}\text { SUDĖTINGIAUSIOS } \\
\text { OPERACIJOS }\end{array}$ & $\begin{array}{l}\text { LABIAUSIAI TIKĖTINOS } \\
\text { OPERACIJOS }\end{array}$ \\
\hline SUNKIOS ŠARVUOTOS & JUNGTINĖS EKSPEDICINĖS \\
DIVIZIJOS & PAJËGOS \\
\hline
\end{tabular}

1 lentelè. NATO dilemos

NATO jau senokai veikia už savo teritorijos ribų - pirmiausia buvo Balkanai, vèliau Afganistanas ir Irakas (su kuklia mokymo misija), Viduržemio jūra, o paskutiniu metu - ir Somalio krantai. Partnerysčių tinklas dar ịspūdingesnis: Euroatlantinès partnerystės taryba apima 22 Taikos partnerystės pogramos nares, Viduržemio dialogą (7 šalys), Stambulo bendradarbiavimo iniciatyvą (4 Persijos ịlankos šalys), ne NATO ISAF dalyviu formatą, NATO - Rusijos Tarybą, NATO - Ukrainos komisiją ir NATO - Gruzijos komisiją bei dvišalius ryšius su „kontaktinèmis šalimis“ - Australija, Japonija, Pietų Korejja, Naujaja Zelandija.

Vis dèlto Aljansas tikrai nèra pasaulio policininkas ir vargu ar siekia tokiu tapti. Be Afganistano, NATO vẻliavos nèra daugelyje pasaulio karštuju tašku. Dar daugiau, kažkas yra ne taip ir su visa Aljanso partnerysčių politika. Suomija ir Švedija, kurios turbūt yra labiau sąveikios su NATO nei dalis dabartinių NATO narių ir reikšmingai prisideda prie NATO operaciju, formaliu požiūriu yra traktuojamos taip pat kaip kitos Taikos partnerystės programos ir Euroatlantinės partnerystės tarybos narès, tokios kaip Turkmėnistanas, Uzbekija, Tadžikistanas, Armėnija ar Baltarusija - valstybės su abejotinais pasiekimais žmogaus teisių apsaugos srityje ir itin menkais demokratiniais kredencialais. Minètos „kontaktinès šalys" „susiduria su panašiais strateginiais iššūkiais ir puoselejja tokias pat vertybes kaip Aljansas"18 ir šia prasme turi daugiau bendra su NATO nei kai kurios formalios partnerès. Nepaisant to, svarbus ju indèlis i NATO veiklą vis dar nesulaukè jokio reikšmingesnio pripažinimo iš NATO pusès.

NATO instituciniu partnerysčiu su kitomis svarbiausiomis tarptautinèmis organizacijomis - JTO ir ES - raida yra apipinta anekdotais. Nepaisant ilgamečio praktinio bendradarbiavimo, NATO ir JTO tik $2008 \mathrm{~m}$. rugsèji sugebëjo pasirašyti formalų dokumentą „konsultacijų ir bendradarbiavimo remams nustatyti“. Tai, kad NATO ir ES santykiai pateko į aklavietę, nepaisant 21 valstybės narystės abiejose organizacijose, yra apskritai vienas gèdingiausiu šiuolaikinès tarptautinés politikos epizodu. NATO nebèra tik regioninis blokas,

\footnotetext{
${ }^{18}$ Oficiali NATO tinklalapio informacija: NATO's relations with Contact Countries, http://www.nato.int/cps/en/SID-B1F50273-84ED580F/natolive/topics_49188.htm, 2009-12-08
} 
tačiau kartu nèra tapusi ir tikrai globaline organizacija. Naujoji Strateginė koncepcija turètų racionalizuoti NATO partnerysčių tinklą ir suteikti jam aiškesnę kryptį bei tikslą.

NATO sukurti bendradarbiavimo ir dialogo mastai byloja apie tai, kad NATO tampa vis mažiau karinis ir vis labiau politinis aljansas. Tuo pat metu galima teigti, kad NATO politinè galia kyla iš jos karinès galios. Šiandien karinè galia nebėra vienintelis ar svarbiausias tarptautinės politikos veiksnys. Vis labiau tarpusavio priklausomybès saitais apipinta tarptautinè ekonomika, konkurencija dèl energijos ir kitų gyvybinių ištekliu, klimato kaita ir besikeičiantis demografinis Vakarų visuomenių veidas, kibernetinės erdvès svarbos (taip pat ir pažeidžiamumo) augimas kasdieniame gyvenime yra pagrindiniai šiuolaikinės tarptautinès politikos bruožai. Nors su NATO kariniu pranašumu niekas negali ir artimiausiu metu negalès varžytis, jis privalèjo atitinkamai reaguoti į šiuos naujus reiškinius, kad jo politinis vaidmuo išliktų adekvatus.

\subsection{Nuo kariavimo iki „visa apimančio požiūrio“?}

Nors NATO lyg ir tebėra skirta sąungininkų saugumo apsaugai (o ne, pvz., ekonominès gerovès skatinimui), vis dèlto, į kurias saugumo grèsmes NATO turètų atsakyti? Bendrosios politinės gairès, savotiška tarpinė naujos Strateginès koncepcijos versija, priimta 2006 m., išskiria dvi pagrindines grèsmes - terorizmą ir masinio naikinimo ginklus. Ši klasifikacija turi tam tikrų teleologinių problemų. Europietiškoje pasaulèžiūroje terorizmas yra daugiau policijos ir kitų teisėsaugos institucijų reikalas. George W. Busho „karas prieš terorą" karinėmis priemonėmis nuvedè į Irako liūną. Legitimesnis šio karo frontas - Afganistanas - primena asimetrini partizanini karą, nors talibai ir nevengia teroristinių metodų. Bet kuriuo atveju būtuc sudètinga NATO - karinį aljansą - paversti tarptautinėmis antiteroristinèmis policijos pajègomis.

Antros grèsmès - masinio naikinimo ginklu platinimo - atveju, NATO pasiekimai labai kuklūs. Operacija „Active Endeavour“ yra labiausiai matoma ir aiškiausia veikla šia kryptimi. Kaip jau minėta anksčiau, NATO nedalyvauja sprendžiant tokiu ,"platintojuc“, kaip Šiaurès Korejja ar Iranas, problemas. Dar daugiau, sajungininkai netgi neturi bendros politikos branduolinio neplatinimo ir nusiginklavimo klausimais. Jie nekoordinuoja pozicijų Branduolinio ginklo neplatinimo sutarties klausimais. Jungtinèse Tautose kai kurie sajungininkai balsuoja už JT rezoliucijas, kurios prieštarauja sutartai NATO branduolinei politikai.

Energetinis saugumas yra kitas naujas ir svarbus tarptautinès politikos sandas. Bendrosios politinès gairès mini „gyvybinių išteklių tiekimo nutraukimą" kaip vieną pagrindinių iššūkių Aljansui. Nors po to sekę NATO vieši pareiškimai ženklina bandymus stiprinti NATO vaidmenį šioje srityje, politiniskarinis aljansas objektyviai turi mažai galimybių spręsti iš esmès politinę-ekonominę problemą. Greitojo reagavimo energetinio saugumo brigadų kūrimas 
siekiant atgrasyti energijos tiekëjus nuo noro panaudoti išteklių tiekimą kaip politini ginklą neatrodo realus ar rimtas politikos variantas.

$2006 \mathrm{~m}$. Bendrosios politinės gairès skelbia, kad „kolektyvinė gynyba išlieka svarbiausias Aljanso tikslas", tačiau šiai nuostatai tuoj pat pateikiama išlyga, $\mathrm{kad}$ „potencialių 5 straipsnio iššūkių pobūdis toliau keičiasi“. Iki galo nėra aišku, ką tai reiškia praktikoje. Pavyzdžiui, kai kurie sajungininkai (ypač Estija 2007 m.) patyrė rimtu kibernetiniu ataku pastaraisiais metais. Taip pat kaip ir energijos resursų tiekimo nutraukimo atveju, tokie saugumo iššūkiai gali rimtai pakenkti socialiniam, ekonominiam ir finansiniam sajungininkų integralumui bei stabilumui ir šia prasme lyg ir atitiktu „,besikeičiančio 5 straipsnio grèsmiu pobūdžio“ aprašymą. Vis dèlto mažai tikètina, kad jie galètų suaktyvinti 5 straipsnį ar juo labiau inspiruoti karinès jègos panaudojimą i juos atsakant. Nauja Strateginė koncepcija turètų suformuluoti aiškesnį šios problemos sprendimą.

NATO galiausiai gali tekti laikytis senu geru principu naujojoje koncepcijoje: pirma, pabrěžti, kad kolektyvinė gynyba yra pagrindinis Aljanso tikslas; antra, sajungininkai greičiausiai patvirtins, kad NATO nèra prieš nieką nukreipta, bet yra už taika, saugumą, stabilumą ir gerovę pasaulyje (apibrèžiant NATO veikimo ribas dviprasmišku ,ten ir tuomet, kai reikès“).

Nors sveikas protas diktuotų NATO būtinybę toliau daryti tai, ką ji išmano geriausiai - gynybos planavimas ir kariniai veiksmai - šiuolaikinių konfliktu pobūdis, kaip rodo Irako ir Afganistano patirtis, dramatiškai keičiasi.

JAV vadovaujama koalicija Irake ir NATO Afganistane pasimoke, kad vien karinio pranašumo nepakanka. Konfliktuojančiu grupuočiu politinis sutaikymas ir ekonominė plètra bei rekonstrukcija yra bene dar svarbesni veiksniai, nes susiję su pačiomis konflikto šaknimis. Sėkmei tokioje sudètingoje aplinkoje kaip Afganistanas reikia tiek įvairių tarptautinių organizaciju glaudaus veiklos koordinavimo politiniu lygmeniu, tiek koordinuotu civiliu ir karių veiksmu praktiniu projektu igyvendinimo lygmeniu. Kampanija jau vykdoma aštuonerius metus, tačiau NATO dẻl kelių priežasčiu iki šiol vargsta su „visa apimančio požiūrio“ (ang. „comprehensive approach“) koncepcija. Pirma, daugelis tarptautinių organizacijų mégsta "koordinuoti“", bet nenori būti „,koordinuojamos“. Pavyzdžiui, JTO laiko save svarbiausia organizacija Afganistane, nors juk NATO sajungininkai neša didžiausią naštos dali. Antra, Aljanso nariai niekaip nesutaria, ar NATO turètų plètoti savo civilinius pajėgumus, ar vis dèlto šioje srityje priklausyti nuo tokių organizaciju, kaip ES, paramos. Ši politine diskusija tęsiasi, nors NATO jau kelerius metus Afganistano atstatymo ir stabilizavimo užduotis igyvendina per civilines-karines provincijos atkūrimo grupes - PAG. Kita problema yra ta, kad kiekviena PAG vadovaujanti šalis vykdo savo nedidelị „,visa apimančio požiūrio“ eksperimentą, mažai ar visai nekoordinuodama veiklos su kitomis valstybėmis, vadovaujančiomis PAG. Taigi Afganistane yra keli „visa apimantys požiūriai“ , bet nėra vienos sutartos NATO politikos.

Tam tikra prasme iš NATO pajègu tikimasi daug daugiau nei kada nors anksčiau. Jos turi būti itin profesionalios ir mokèti naudotis pažangiomis technologijomis, tokiomis kaip bepiločiai orlaiviai, ypač taiklus ginklas ar kiti 
"tinklo igalinti“ pajègumai (ang. „network enabled capabilities”). NATO pajègos turi būti greitai perdislokuojamos ị tolimus kraštus, kuriuose gali sulaukti mažai ar visai nesulaukti priimančiosios šalies paramos. NATO pajègos turi gebėti vykdyti jungtines daugianacionalines ekspedicines operacijas priešiškoje aplinkoje. Jos turi gebėti ir kariauti, ir padèti statyti ligonines bei mokyklas vienu metu tame pačiame operacijų rajone. Jos nebėra tik kariai. Jos kartu ir gentinès diplomatijos ekspertai, islamo ir vietinès kultūros žinovai. Toks mąstymas apie naujus reikalavimus karinėms pajėgoms sudarė NATO greitojo reagavimo pajègų idejjos pagrindą. Šias pajègas turëjo sudaryti 25000 kariu, pasirengusiu "viso spektro" misijoms - nuo humanitarinès pagalbos iki 5 straipsnio - bet kuriame pasaulio taške. 2006 m. Rygos viršūnių susitikime NATO paskelbẻ visišką greitojo reagavimo pajègu operacinę parengtį tik tam, kad ji po keliu mènesių būtų atšaukta, nes NATO narès nuolat nepateikdavo reikiamo kiekio reikalingu pajėgumų.

$2006 \mathrm{~m}$. Bendrosiose politinėse gairèse pateiktas NATO ambicijų lygio apibrèžimas yra gana dviprasmiškas: „NATO turi išlaikyti gebejjimą igyvendinti visą spektrą misiju, nuo aukšto iki žemo intensyvumo, ypač pabrèžiant labiausiai tikètinas operacijas, reaguojant į dabartinius ir būsimus operacinius reikalavimus, bet kartu ir sugebėti vykdyti sudètingiausias operacijas. "19

Ši nuostata atspindi bandymą rasti nelengvą balansą tarp poreikio daugiausia dèmesio skirti „labiausiai tikètinoms operacijoms“ kaip Afganistanas ir tuo pat metu išlaikyti gebẻjimą reaguoti i̇ mažiau tikètinus, bet daugiau reikalaujančius konvencinius scenarijus.

Turint omenyje, kad Afganistane nuolat trūksta tam tikrų pajėgumų ir nesugebama sugeneruoti greitojo reagavimo pajėgu, būtų galima kelti klausimą, ar NATO sugebėtų imtis dar vienos didelès atsako į krizę operacijos, lygiagrečiai su ta, kuri vykdoma Afganistane? Atsakymas turbūt priklausytu nuo JAV įsitraukimo lygio. Visgi daugelis sąjungininkų vienu metu dalyvavo tiek ISAF, tiek Irako operacijoje, nors pastaroji ir nebuvo vykdoma su NATO vèliava. Obamos administracijos pradètas pajègų mažinimas Irake leido JAV skirti daugiau dèmesio ir pajègu Afganistanui. Bet kuriuo atveju įtampa dèl skirtumo tarp politiniu ambiciju ir turimų išteklių turbūt išliks ir ateityje, nes, be keleto išimčiu (JAV, Prancūzija, JK, Turkija ir Graikija), gynybos išlaidos daugelyje kitų NATO šalių pastaraisiais metais ne tik nedidejo, bet ir mažèjo.

Papildomą susirūpinimą kelia Aljanso gynybos planuotojų strateginio situacijos vertinimo galimybės. Kariškiai turi blogą îprotį ruoštis „pastarajam karui“. Šiandien pagal „labiausiai tikètinus“ scenarijus daroma prielaida, kad kitas konfliktas bus panašus į Afganistano tipo kontrterorizmo, stabilizavimo ir rekonstrukcijos pastangų kompleksą, kovojant su asimetriniu ir kariniu

\footnotetext{
${ }_{19}^{1}$ Žr.: Comprehensive Political Guidance, Endorsed by NATO Heads of State and Government on 29 November 2006, http://www.nato.int/cps/en/SID-94B7F554-9A0B094E/natolive/official_texts_56425.htm, $2009-11-25$
} 
požiūriu gerokai silpnesniu priešu. Karas Gruzijoje buvo visiško kitokio tipo konflikto pavyzdys - trumpo, bet pakankamai žiauraus tarpvalstybinio susidūrimo, kuriame abi pusés naudojo tankus, aviaciją ir artileriją (Afganistane talibai daugiausia naudoja lengvuosius šautuvus ir improvizuotus savadarbius sprogmenis!). NATO daugiausia dėmesio skiria plètrai lengvu, ekspediciniu pajėgu, kurios yra gerai pasirengusios asimetrinei kovai. Ar tos pačios pajègos tikrai galètų taip pat sẻkmingai kariauti konvencinį karą prieš sunkias, šarvuotas oponento pajègas?

Turbūt vienintelè šalis, remiama keleto sajungininku (daugiausia iš Centrinės Azijos), kuri turi potencialą ir galbūt net motyvą mesti karinį iššūkị kai kurioms kaimyninėms NATO šalims, yra Rusija. Pagal bet koki kriteriju Rusija pralaimètų didelio masto konvencinį karą prieš NATO. Vis dèlto labai hipotetiniu atveju du veiksniai šią paprastą analizę komplikuotu. Pirma, klausimas išlieka atviras, kaip greitai ir kokiomis priemonemis NATO reaguotu ị toki iššūkị. 5 straipsnis greičiausiai būtu suaktyvintas, bet atsako pobūdis būtų ilgos diskusijos Šiaurès Atlanto Taryboje. Turbūt didžiausias nežinomasis šioje lygtyje yra tai, ar Rusija tiki NATO solidarumu tuo atveju, kai reikia ginti mažesnes ir silpnesnes sajungininkes?

Iš Rusijos perspektyvos, greita karinè invazija su ribotais tikslais (pvz., krizės suvaldymo, atsako į terorizmą, "piliečių" apsaugos ar kitu pramanytu pretekstu) į neginamą NATO narę nèra visiškai neįsivaizduojama, ypač remiantis Gruzijos - NATO partnerės, kuriai pažadèta narystė, pavyzdžiu. Kitas $\mathrm{X}$ veiksnys yra Rusijos branduolinè doktrina, kuri labai aiškiai numato "pirmo panaudojimo“ galimybę net regioniniame konflikte, jei tik jis grasina Rusijos interesams. Toks jau sutapimas, kad Rusija turi tūkstančius taktiniu branduoliniu ginklu, įskaitant europinę Rusijos dalị. Nors vẻlgi, visa tai yra labai hipotetiška, tarptautinės politikos dinamiką labai sunku prognozuoti. Tolesnis ekonomikos nuosmukis, Rusijos kariškių ir visos visuomenès augantis nepasitenkinimas, socialiniai neramumai gali sukelti Rusijos lyderiu norą nukreipti dèmesį nuo vidaus problemų į išorès „priešus“.

Aišku, kad naujoji Strateginè koncepcija greičiausiai nepakvies NATO "grižti namo ${ }^{\prime 20}$. Vis dèlto Aljansui reikètų pergalvoti įvairias galimas kritines situacijas, kad ir kokios mažai tikètinos jos šiandien atrodo, ypač jei tos situacijos gali tiesiogiai grasinti Aljanso teritorijai ir gyventojams.

\section{Penki narystès metai - blèstantis entuziazmas?}

Strasbūro/Kèlio viršūnių susitikimas sutapo su penktosiomis 7 „naujesnių“ sajungininkiu, ịskaitant Lietuvą, narystès metinèmis. Nors Strasbūre priimtą NATO komunikatą kai kurie Lietuvos apžvalgininkai perskaite

\footnotetext{
${ }^{20}$ Ringsmose J., Rynning S., "Come home, NATO? The Atlantic Alliance's New Strategic Concept”, DIIS Report, 2009, no 4, (Danish Institute for International Studies), http://www.diis.dk/graphics/Publications/ Reports2009/DIIS_report_200904_RingmoseRynning_NATO_web.pdf, 20100510.
} 
klaidingai, ${ }^{21}$ buvo iškeltas svarbus klausimas - ar Lietuva jau tapo neatskiriama NATO dalimi ir atsikratė sau įsiteigto buvimo euroatlantinės ervès periferija komplekso? Juk politinè geografija yra mentalinis, o ne materialaus pobūdžio fenomenas.

Šio straipsnio autorius jau yra teigęs anksčiau, kad Lietuvai „vakar atejo staiga“".22 Pasiekdama du didžiausius istorinius tikslus - narystę NATO ir ES, Lietuva kartu prarado svarbiausius strateginius orientyrus. „Būti aktyvia NATO ir ES nare" - nuolatinis įvairių Lietuvos užsienio ir saugumo politiką reglamentuojančių dokumentų šūkis nebeapima tos strateginès svarbos ir skubos, nepatraukia dèmesio ir neįkvepia susižavẻjimo visuomenei. Nors dideliu istorinių pasiekimų Lietuvos sprendimų prièmėjams horizonte nebesimato, įvairių iššūkių ir dilemų yra daugiau nei pakankamai.

5 narystès NATO ir ES metai daugeliu atžvilgių buvo įdomių atradimų laikotarpis. Pirma, nors Lietuvos politikai ir pareigūnai siekè euroatlantinès integracijos ir traktavo NATO kaip "griežtojo“ saugumo, o ES - kaip „ک̌velniojo" saugumo garantus, t.y. dvi vienos monetos puses, paaiškèjo, kad abi organizacijos yra gana skirtingi, o kartais net konfliktuojantys gynybos veikejjai, turintys skirtingų ambicijų ir skirtingą institucinę struktūrą toms ambicijoms igyvendinti. Dar daugiau, abi organizacijos iš esmès yra tarptautiniai veikejjai, turintys pasaulinius partnerysčių tinklus ir atitinkamai projektuojantys savo veiklą, o Lietuvos interesai ir rūpesčiai objektyviai apsiriboja Baltijos regionu. Pagaliau Rusiją dauguma NATO ir ES narių mato kaip svarbią ar net „,strateginę" partnerę, o Vilniui ji tebèra strateginio lygmens saugumo problema.

Nauja NATO strateginè koncepcija Lietuvai yra svarbi dèl dviejų priežasčių. Pirma, Lietuva dar nebuvo narè, esant pastarajai - 1999 metu - koncepcijos versijai. Taigi bent jau formaliai Lietuva kartu su kitomis naujomis naremis turi galimybę kurti Aljanso ateiti. Paradoksalu, tačiau naujoji koncepcija greičiausiai pastums NATO dar toliau nuo tos saugumo vizijos, kurią Aljanse regëjo lietuviai. Antra, tai yra puiki galimybė Lietuvos sprendimu prièmejjams dalyvauti intelektiniame savianalizès procese, ieškant naujos, aiškios nacionalinio saugumo vizijos, t.y. apsispręsti, kokioje saugumo aplinkoje Lietuva nori gyventi, kokios grèsmès yra pavojingiausios ir kokiomis priemonemis (tiek nacionalinėmis, tiek daugianacionalinėmis) iz jas reikètų atsakyti.

Tai gali tapti ir „entuziazmo pažabojimo" pratimu. Kai Lietuva jungèsi prie NATO, buvo padaryta nemaža drąsių prielaidų dèl gynybos planavimo. Śios prielaidos sudarè didelès gynybos reformos pagrindą. 2-oje lenteleje pateiktas palyginimas rodo, kad kol kas ne visos prielaidos išlaikè patikrinimą realybe, tačiau ir ne visos buvo klaidingos.

\footnotetext{
${ }^{21}$ Samoškaitė E., "NATO aljansui esame periferija?", Delfi.lt, 2009 m. balandžio 4 d., http://www.delfi.lt/ news/daily/lithuania/article.php?id=21326605, 20100520.

${ }^{22}$ Paulauskas K. "Yesterday Came Suddenly: the Brave New Security Agenda of the Baltic States", in : Tiirmaa-Klaar H., Marques T., eds, Global and regional security challenges: A Baltic Outlook, Tallinn University Press, 2006, p. 15-41.
} 
2 lentelè. Lietuvos gynybos planavimo prielaidos ir realybè

\begin{tabular}{|c|c|}
\hline 2004 m. prielaidos & $2009 \mathrm{~m}$. realijos \\
\hline $\begin{array}{l}\text { Lietuvos kariuomenei nereikès kariauti vienai } \\
\text { - didelès šauktinių kariuomenès nereikia }\end{array}$ & $\begin{array}{l}\text { NATO neturi Baltijos valstybių gynybos } \\
\text { planu, bet vyksta neformalus planavimas }\end{array}$ \\
\hline $\begin{array}{l}\text { Atgrasinimui sustiprinti NATO dislokuos } \\
\text { greitojo reagavimo pajejgas pajeggas iki krizès } \\
\text { eskalacijos }\end{array}$ & $\begin{array}{l}\text { NATO persitempusi Afganistane, o greitojo } \\
\text { reagavimo pajègos nefunkcionalios }\end{array}$ \\
\hline Lietuva Afganistane, o NATO Lietuvoje & $\begin{array}{l}\text { NATO oro policijos misija tęsiama, bet } \\
\text { NATO sausumos pajègų pratybos Baltijos } \\
\text { valstybèse nevyksta }\end{array}$ \\
\hline Teritorinès gynybos pajègumai nereikalingi & Konvenciniai scenarijai nèra neįmanomi \\
\hline
\end{tabular}

Pirmiausia ir svarbiausia, 5 straipsnio patikimumas Lietuvoje buvo laikomas neginčytina duotybe. Sulaukę pakvietimo Lietuvai tapti NATO nare, Lietuvos sprendimu prièmëjai, ir ypač krašto apsaugos sistemos vadovybė, galëjo sutelkti dèmesį i gynybos peržiūros procesą, kurio reikalavo NATO pareigūnai. NATO kolektyvinès gynybos principas reiškia, kad jokiam sajungininkui neteks vienam kovoti su jo teritorijai ar gyventojams kylančia grėsme. Už tai kiekvienas sajungininkas turi prisiimti garbingą kolektyvinės gynybos naštos dalį. Atitinkamai Lietuva turèjo suvokti, kad NATO kolektyvinè gynyba nèra skirta Lietuvai, bet visam Aljansui.

Remiantis šia logika, Lietuvos kariuomenè iš didelès, prastai ginkluotos, prastai apmokytos ir nemobilios šauktinių kariuomenès, gebančios vykdyti tik ribotas teritorinès gynybos užduotis, buvo reorganizuota i̇ mažesnes, bet geriau ginkluotas ir geriau parengtas profesionalias pajėgas, galinčias generuoti ir dislokuoti specializuotus pajëgumus NATO operacijoms. Nuo 1994 $\mathrm{m}$. Lietuva jau sukaupe nemažą dalyvavimo tarptautinėse operacijose patirti, kurios kulminacija buvo $2005 \mathrm{~m}$. sprendimas prisiimti atsakomybę už visos Goro provincijos, esančios kalnuotame Afganistano centre, atkūrimą. Šis sprendimas tapo principo „Lietuva Afganistane, o NATO Lietuvoje“ simboliu. Net jeigu Afganistanas pats savaime nèra itin svarbus Lietuvos nacionaliniam saugumui ir gynybai, bet, kaip buvo minėta, jis yra aukščiausias prioritetas visam NATO. Tik laikydamasi solidarumo su kitais sajungininkais principo Lietuva prireikus gali tikètis tokio pat solidarumo iš sajungininkų. Lietuvos atveju šis solidarumas turi vieną apčiuopiamą išraišką: nuo pat $2004 \mathrm{~m}$. balandžio $30 \mathrm{~d}$ vykdomą NATO oro policijos misiją Baltijos valstybėse, kurią numatomą tęsti bent iki $2014 \mathrm{~m}$.

Kita vertus, kai kurios saugumo problemos išlieka. Karas Gruzijoje parodè, kad konvenciniai konfliktai tarp Europos valstybių negali būti laikomi visiškai neįmanomais ateityje. Lietuva ir kitos Baltijos šalys, bent jau geografiniu požiūriu, yra Aljanso pakraštyje esančios atidengtos teritorijos, 
kurios iki narystės NATO buvo laikomos „neapginamomis“23. Turint omeny daugelį dvišalių santykių su Rusija problemų, Rusijos lyderiai gali jausti tam tikrą pagundą išbandyti Aljanso vienybès ir ryžto ribas, bent jau kaip rodo didžiausios nuo Sovietų Sajungos griūties laikų karinès pratybos "Zapad" ir „Ladoga“, vykusios visai šalia Baltijos valstybių 2009 m. rudenį. Pačios Baltijos šalys dažnai kèlė klausimą, ar kolektyvinė gynyba gali būti patikima nesant aiškių tokios gynybos planų. Šios dvejonès galiausiai buvo daugiau ar mažiau išsklaidytos, kai NATO prièmè sprendimą parengti formalius Baltijos šaliu gynybos planus, ${ }^{24}$ iš dalies atsakant į pastaruoju metu prasiveržusį Rusijos karinį avantiūrizmą.

Penkerių metų narystės patirtis nevienareikšmè. Lietuva toli pažengè keisdama savo mąstymą apie saugumą, reformuodama savo kariuomenę ir adaptuodama savo elgesi prie Aljanso. Lietuva gerai išmoko erzinti sajungininkus griežta pozicija Rusijos atžvilgiu, energetinio saugumo ar Ukrainos ir Gruzijos narystès NATO klausimais. Lietuva taip pat gerai moka priderinti savo poziciją prie didesnių ir galingesnių sajungininkių - ypač JAV ir JK politikos. Lietuvos gynybos planuotojai nèra iki galo įtikèję „ekspedicine" anglosaksu filosofija, tačiau ta filosofija bent jau numato stipru ir efektyvu NATO, skirtingai nei kai kuriose Vakarų Europos šalyse stiprëjančios nuotaikos, kad NATO tikslas jau atgyveno. Pagaliau tais atvejais, kai galimybès „erzinti“ arba „prisijungti“ yra išnaudotos, Lietuvai dažnai lieka tik susitaikyti su besiformuojančiu konsensusu.

Lietuvai dar reikia įvaldyti pozityvesnị "Taip, mes galime“ požiūri, išmokti prastumti savo interesus į NATO darbotvarkę ir tapti NATO sprendimu priėmimo subjektu, ne vien objektu. Pavyzdžiui, lietuviams (taip pat ir estams, latviams) iki šiol nepavyko gauti jokio svarbesnio NATO tarptautinio personalo posto. Nors atranka į aukščiausius postus yra politinis ir dažnai net labai politizuotas procesas (kaip parodė Turkijos išsiderèta nauja generalinio sekretoriaus pavaduotojo pozicija mainais į Turkijos paramą Danijos kandidatui i generalinio sekretoriaus postą), žemesnio rango pozicijos yra atviros visiems sajungininkams. Postų pasidalijimas atspindi santykinį sajungininkų politinị svori ir kartu yra netiesioginė įtakos NATO sprendimu prièmimo procesui priemonè. Baltijos šalių tas svoris tebėra mažiau negu reikšmingas.

\footnotetext{
${ }^{23} \mathrm{Z}$ r.: Dalsjo R. "Are the Baltics defensible? On the utility of and prospects for a capability for self-defence", RUSI Journal, London, 1998.

${ }^{24}$ Žr.: "Thanks to Poland, the alliance will defend the Baltics", The Economist, January 14, 2010.
} 


\section{Išvados}

NATO dar nèra pasirengusi išeiti i pensiją ir neturètu to daryti. Kita vertus, globalinės ambicijos, paremtos neadekvačiais ištekliais ir netvirta visuomenès parama, negali būti palaikomos neribotą laiką. Aljansui gali tekti apsispręsti dèl savo ateities, o ne tiesiog rasti balansą. Viena alternatyva yra išlikti unikalia karine organizacija, pasirengusia bet kokiai netikètai krizei, kuriai išspręsti reikia moderniu koviniu pajėgu, gebančių tiek atgrasinti potencialu priešą nuo agresijos prieš sajungininku teritoriją ar gyventojus, tiek vykdyti chirurgines ekspedicines intervencijas bet kuriame pasaulio taške. Kita alternatyva yra visuotinis, daugiafunkcinis (taigi ir dažnai fragmentuotas) politinio dialogo forumas, užsiimantis politinemis konsultacijomis su įvairiausiomis šalimis ir organizacijomis, o retkarčiais teikiantis humanitarinę pagalbą ir vykdantis îvairias civilines-karines operacijas. Šiandien NATO, atrodo, yra įstrigusi tarp šiu dviejų alternatyvų. Pavojus susijęs su tuo, kad, bandydama siekti abieju, NATO gali nepasiekti nei vienos alternatyvos, nebent sajungininku vyriausybès skirtu kur kas daugiau išteklių ir politinės valios NATO ambicijoms igyvendinti, o tai yra mažai tikètina.

Operacija Afganistane yra ypač svarbus tolesnès Aljanso raidos veiksnys. NATO vadovybės nuomone, sẻkmè Aljanse netgi gali lemti NATO adekvatumą ateityje. Be to, NATO vykdo kovos su piratavimu misiją prie Somalio krantu, NATO laivai patruliuoja Viduržemio jūroje, kovodami su terorizmu ir masinio naikinimo ginklu platinimu, palaiko taiką Kosove ir moko Irako pajėgas. Kita vertus, NATO nedalyvavo sprendžiant kitas dideles krizes, tokias kaip konfliktai Artimuosiuose Rytuose ar karas Gruzijoje. Irano ir Šiaurès Korëjos problemos taip pat sprendžiamos kitu tarptautiniu formatu. Nors $1999 \mathrm{~m}$. strateginè koncepcija NATO laikè svarbiausiu transatlantinio politinio dialogo forumu, NATO nepaskelbe aiškios pozicijos daugeliu iš minètų klausimu, išskyrus pavienius "susirūpinimus“ ir ",apgailestavimus“. Tik Kim Čong Ilo branduolinès šèlionès sulaukè "stipraus pasmerkimo“ iš sajungininku pusès.

Ir vis dèlto NATO visais požiūriais tebèra galingiausia saugumo organizacija pasaulyje. Jokia kita saugumo organizacija nesugebëjo sutvarkyti Balkanų chaoso, kol NATO nepradëjo savo operacijos „Deliberate Force” ir SFOR misijos Bosnijoje ir Hercegovinoje (būta nuomoniu, kad JAV sąmoningai leido europiečiams ,"susimauti“ Balkanuose, kad jie pasimokytų nuolankumo ir suvoktų amerikiečių vaidmens nepakeičiamumą Europos saugumo reikaluose). Tik NATO turëjo pakankamai valios ir karinès galios sustabdyti kraujo praliejimą Kosove. Pagaliau tik NATO šiandien sugeba vykdyti tokią sudėtingą misiją kaip ISAF Afganistane.

Aljanso misiju spektras ir partnerysčiu tinklas ịspūdingai išsiplètė po šaltojo karo. NATO šiandien yra daug globalesnè ir daug labiau "politinè“ organizacija nei anksčiau. Kita vertus, NATO "transformacijos“ mantra gali slëpti tam tikrą krypties praradimą, jeigu ne politinės ir karinès galios degradaciją. Kad NATO išliktų adekvati dinamiškai saugumo aplinkai, sajungininkai 
ieško būtų įsitraukti į naują veiklą tokiose srityse kaip energetinis saugumas ar kibernetinė gynyba. Vis dèlto, atidžiau panagrinejjus, tokios sritys sunkiai patenka po tradiciniu pagrindinių užduočių - kolektyvinès gynybos ir atsako i krizes - apibrěžimu.

Jeigu senesni Aljanso nariai kenčia nuo "plètros nuovargio“, naujesni nariai ima rodyti tam tikro nusivylimo ir mažëjančio entuziazmo ženklų. Vis dèlto galima tikètis, kad tokios jaunos demokratijos kaip Lietuva anksčiau ar vèliau subręs ir taps visaverčiais ir nepakeičiamais Aljanso nariais. Būtu galima teigti, kad Lietuva jau šiandien neša užtektinai garbingą naštos dali NATO operacijose, tačiau ši našta dar turi virsti didesniu politiniu svoriu ne tik Čagčarane, bet ir Briuselyje.

Galiausiai galima teigti, kad NATO pirma ir svarbiausia paskirtis yra visu sajungininkų saugumas ir gynyba, kad ir ką tai reiškia skirtingose sostinėse. Kol NATO tęsia savo adaptacijos ir rekonstrukcijos projektą, sajungininkai turètų nepasiklysti transformacijoje ir nepamiršti šios paprastos, bet esminès prielaidos. 